\title{
Meditation Tourism, Buddhist Philosophy in Practice: A Case Study of Lumbini, Nepal
}

\author{
Netra Prasad Sharma \\ PhD Scholar, Lumbini Buddhist University \\ netra.acharya@gmail.com
}

Two roads diverged in a wood, I took the less travelled by, and that has made all the difference.

(Frost, 1984, p. 131)

Article History

Received 26 April 2019

Accepted 29 July 2019

Keywords

Meditation tourism, Lumbini, Spiritual tourism, Buddhist meditation, Compassion
Corresponding Editor Ramesh Raj Kunwar kunwar.dr@gmail.com

\begin{abstract}
The dimensions of travelling and tourism have become manifold in recent decades. People love to travel with various purpose. Religious tourism, yoga tourism, peace tourism and spiritual tourism are some dimensions. Lumbini can be a best destination for meditation tourism, which could be much rewarding for individual, social and national development. The travelers and stakeholders have yet to be aware of this aspect. In Buddhism, Lumbini is a best destination for meditation tour. Exploring the importance of travelling Lumbini for meditation is the main objective of this article. Tourists and pilgrims would benefit immensely if they understand the significance of meditation tourism to Lumbini, its philosophy and practice. This article aims to explore the spiritual significance of Lumbini and it will provide visions of a purposeful development and publicity that would shape Lumbini as a best destination for meditation tourism. The government and private sectors are interested to develop Lumbini as best tourist destination. People all over the world are attracted to visit Lumbini for different reasons. Most tourists are unaware of the core aspect of visiting Lumbini. People who visit Lumbini are unaware about meditation
\end{abstract}


practice or involving in charity works. Meditation and compassion are the core aspects of Buddha's teachings, which are neither realized nor practiced. There seems a vast gap between the actual philosophy of Buddhism and the attitude of most of the visitors. This research study attempts to reveal the significance of meditation tourism in Lumbini.

\section{Introduction}

The word tourism is formed from the verb tour meaning 'travel.' Tourism offers countless opportunities of generating revenues, earning foreign exchange, providing employment and enriching the life of travelers. As tourism is associated with yoga or other spiritual aspects, the benefits of tourism become manifold. Nowadays, such tourism is believed to offer realization of the true self, peace of mind, a feeling of love towards all and endless happiness. Now, tourism is expected to develop harmony, goodwill and connectedness with all. In this literature review, a survey is conducted to identify what spiritual tourism or yoga tourism or peace tourism mean, what are the rewards of such tourism and what are the essential perspectives still lacking.

Lumbini, the birthplace of Gautama Buddha, is situated $290 \mathrm{~km}$. Southwest from Kathmandu. Lumbini is popular as Buddhist pilgrimage site, which incorporates many other sacred sites such as Kapilvastu - Tilaurakot (where Buddha lived till he was 29 years) situated towards western part of Lumbini, Devdaha (Buddha's maternal home) situated towards eastern part of Lumbini, Ramgram (the famous stupa with Buddha's relics). Lumbini area is one of the best place for practicing meditation, experiencing positive energy and involving in charity works. As Buddhism is flourishing everywhere, the birthplace of Buddha is gaining popularity as the fountain of world peace.

Except Mayadevi temple, the birthplace of Buddha, there are several tourist attractions in Lumbini. Inside the sacred zone, Puskarini, Ashoka pillar, Bodhi trees, World Peace Pagoda are the major attractions. In monastic zone, monasteries representing art and architecture of several countries like Sri Lanka, Thailand, China, Myanmar, Cambodia, India, Canada and Germany are built. Those monasteries also represent different types of Buddhist culture and meditation system developed in respective countries. Almost every monastery runs at least one meditation retreat once a year. Tibetan monastery runs meditation retreats according to Kagyu, Shakya, Ningma and Geluk tradition. Lumbini Museum, Golden Temple of Myanmar are other attractions. Lumbini area is developed as a mini Buddhist world in which a tourist finds an appealing environment for meditation and compassion.

In Lumbini, mediation tourism could flourish which would help millions of Buddhist devotees and lay practitioners worldwide. However, until now, Lumbini has not been able to attract visitors for the purpose of meditation and other dharma practices. It is due to lack of understanding, vision or willingness in the stakeholders. 
Lumbini is the birthplace of Buddhist philosophy as well. Mahayana texts reveal this fact in detail, which will be explored below.

The research questions are what is the spiritual significance of Lumbini according to Buddha? Why visitors are not aware of meditation practice and compassion? Why Lumbini is lacking adequate meditation centers? Why there is vast gap between spiritual significance of Lumbini and visitors' activities? Pilgrims would benefit immensely if they understand the significance of Lumbini regarding its philosophy and practice.

The objective of this research is to explore the authenticity of meditation tourism in Lumbini, establishing the relation between Buddhism and tourism and the potentiality of meditation tourism in Lumbini. The objective of this article is to explore the spiritual significance of Lumbini. Another objective is to explore ways of a purposeful development and publicity of Lumbini that would shape this holy place as a best destination for meditation tourism and putting Buddhist philosophy into practice.

The significance of this study is to highlight on meditation tourism in Lumbini. At the same time, this study will fulfill a research gap between the tourist activities in Lumbini and the actual Buddhist philosophy and practice. Based on Buddha's teachings, Buddhist scholar's opinions, experiences of visitors in Lumbini, this study explores the above mentioned objectives. This study covers the area of meditation tourism in Lumbini, relation between Buddhism and tourism, the present scenario and future potentiality.

\section{Methodology}

Qualitative, quantitative and mixed methodologies are utilized in most academic research works. Qualitative research is considered best for researching questions such as why and how of human experiences. "Qualitative research answers why and how a certain phenomenon may occur rather than how often" (Berg \& Lune, 2012, p. 3). It focuses mostly on human elements, concepts and characteristics of social sciences. In this article, qualitative research methodology is applied and textual study is followed mostly to collect non-numerical data and observations. While studying the development and evolution of meditation tourism and while depicting the present scenario at this specific moment of time, diachronic and synchronic approaches are applied respectively. This study quotes Buddha's teachings on meditation from the original Pali canons and Sanskrit texts, which has been mentioned with diacritical marks. The historiography will help to understand the concept of meditation travel in Lumbini according to Buddhist approach. It also includes first-hand experiences of 16 visitors from France who were in meditation tour in Lumbini. As far as field work is concerned, it is confined to Lumbini sacred zone. This tour was conducted for 13 
days (from 11 May 2019 to 23 May 2019), which was managed by a tour operator in Kathmandu.

\section{Types of tourism}

In recent time, several types of tourism are developed such as religious tourism, peace tourism, yoga tourism, spiritual tourism and so on. These types are contributing to wellness tourism. A short introduction of these types of tourism is useful to develop the background of the research.

\section{Religious tourism}

Religion is one of the key motivator to travel. Hinduism expects its practitioners to visit sacred places (tìrtha) for religious purpose such as receiving blessing of particular God or Goddess, purifying oneself from the sins committed or collecting merit (punya). Hinduism has wider sense of understanding of pilgrimage. For Hindus, practicing Dharma is a tirtha, following the way of non-violence is a tirtha, having compassion towards those who are suffering is also a tìrtha (satyasya vacanam tìrtham ahimsā tīrthamucyatē. tapastīrtham dayā tìrtham śilam tīrtham yudhiș̣thirah. alpasantōṣaṇam tīrthai் nārī tìrtham pativratāh) (Ganguli, 2003).

In Buddhism, Buddha suggested his followers to visit four monumental places where the Enlightened One was born, attained enlightenment, delivered first sermon and the place of demise. Religious tourism incorporates visits to religious settings, which are regarded as relevant to one's own faith or the faith of fellow humans.

Religious tourism is "visiting sacred places to participate or follow-up in religious ceremonies and the pilgrimage in the form of visits or activities to fulfill religious duties in the evaluation of tourism understanding" (Heidari, Yazdani, Saghafi \& Jalilvand, 2018). Studies have found that in context of religious tourism, travel behavior, travel patterns, transportation choices and socialization processes are affected by particular beliefs.

In most cases, visitors tend to travel religious places with family members. It is observed that a faith group or a cult organizes people to travel in groups. Such trips are mostly seasonal. The core activity of most religious sites is prayer and worship. However, the travelers may not have the spiritual motives to visit religious sites.

\section{Peace tourism}

Luis D’ Amore (Kunwar, 2006) propounded the concept of peace tourism. Peace tourism is another phenomena growing as unique genre of tourism. Definitions of peace tourism vary; however, the core aspect of peace tourism is to realize inner peace and work for world peace through visiting places. Medhakar \& Haq (2019) say, 'Peace tourism is defined as a phenomenon where every tourist's activity should be linked with peace as the aim for the visitors: locals, domestic or international visitors. 
For example, these activities could be as simple as shopping, eating at restaurants, skiing, visiting heritage buildings and forts, places of worships, gardens, zoo or bird sanctuary, education, conference, art, culture and literary festivals and gatherings" (pp. 22-49).

Studies about tourism's role in promoting world peace are growing in countless numbers. Internationally known personalities have postulated this proposition with significant evidences. Religious Gurus or political leaders are quoted indicating how tourism helps in building world peace. Its advocates assume that indivisible peace can be achieved if a wide understanding in international level could be developed. 'As people move throughout the world and learn to know each other's customs and to appreciate the qualities of individuals of each nation, we are building a level of international understanding which can improve the atmosphere of the world peace" (Pratt \& Liu, 2015).

In this regard, Pope John Paul II is quoted saying, 'The world is becoming a global village in which people from different continents are made to feel like nextdoor neighbors. In facilitating more authentic social relationship between individuals, tourism can help overcome many real prejudices and foster new bonds of fraternity. In this sense, tourism has become a real force for world peace" (Pratt \& Liu, 2015).

(Lollis, 2014; in Karki, 2018, p. 98) defines "peace tourism as travelling to experience places that authentically represent peace stories and peacemakers of the past and present. Peace activities require varying degrees of planning and preparation but peace places, primarily monuments and museums, are static and available to the tourist most of the time... The writer Lollis suggests peace as a destination because, according to him, historical or mythical places of peacemakers can be best choices for peace tourism. Exploring the connection between peace and tourism is going on in academia. Moufakkir \& Kelly (2010) say, 'Travelers may undertake new experiences; gain knowledge of other cultures, regions and countries; discover the importance of caring for the environment; develop new friendship; and in the process, promote peaceful relations among people. Travelers also help in economic growth of the place they visit; it helps to promote culture of peace" (p. 13).

Buddharakshita (1985) Buddha says in Dhammapada, "Hatred is never appeased by hatred in this world. By non-hatred alone is hatred appeased. This is the eternal law. na hì verena verānì ,sammaìtìdha kudācanama, averena ca sammanti, esa dhammo sanaintan" (Verse 5).

\section{Yoga tourism}

Man's quest for something higher than himself or herself is the motivational factor for trying or applying new things in life. In recent decades, yoga tourism is gaining popularity for several reasons. Yoga tourism provides an opportunity for yoga 
tourists to experience physical and psychological well-being during their journey and later as well. Results suggest that yoga tourism has the ability to transform the lives of participants on varying levels (Dillette, 2019). Satyananda (2002) explains, the word 'yoga' is derived from the Sanskrit word $y u j$, which means 'to join'. It is the union of individual consciousness with the universal consciousness. In practical level, yoga is a means of balancing and harmonizing the body, mind and emotions (p. 1).

Yoga tourism and spiritual tourism are considered as interrelated phenomena. Bowers \& Cheers (2017) write, yoga tourism and spiritual tourism sit under the wider umbrella of wellness tourism. Yoga tourism is considered to lead towards personal transformation. The proponents of yoga tourism aspire that yoga helps to achieve personal transformation by uniting mind, body and the spirit. Several cities of India and Nepal are gaining popularity for yoga tourism. The natural environment, the sacred places associated with great yogis and the availability of yoga instructors are the major factors attracting yoga tourist.

A significant number of academic research are conduced to examine the transformative potential of yoga tourism on individual and on social sector. It is widely believed that the travelers who practice yoga grow harmonious, develop acceptance of different cultures, tradition and people, and build psychological, emotional and spiritual wealth. The ancient texts say that Yoga practice is transforming a seemingly limited physical, mental and emotional person into an enlightened, harmonized and impartial being. In recent times, yoga practice is applied as alternative therapy for people suffering from psychological and emotional problems. Yoga instructors are supposed to act as catalysts for open-mindedness. Yoga tourists are influenced by the communities they visit, they get inspired by the nature and the spiritual aspect of nature. This wandering connects a traveler to the spirit of ancestors who were great travelers. The transformation is achieved by the practice of the eight limbs of yoga, considered as eight guiding principles to attain the state of peacefulness. In eight limbs of yoga, meditation is the seventh limb (Patanjali, 1998, 2.29).

The yoga practitioners act as catalysts of open-mindedness. In yoga tourism, yoga practitioners are influenced in two ways: by the communities they visit and the yoga they practice. The research has explored that 'the transformative power of travel experience and yoga practices stimulates metaphysical change in self and surroundings" (Ponder \& Holladay, 2013). These authors have investigated how yoga tourism has the capacity to transform communities towards enlightenment and acceptance, while building psychological, emotional and spiritual capital.

The authors have presented the transformative aspect of yoga in beautiful way: 'Its ultimate aim is to bring about a thorough metamorphosis of the individual who practices it sincerely. Its goal is nothing less than the total transformation of 
a seemingly limited physical, mental and emotional person into a fully illumined, thoroughly harmonized and perfected being - from an individual with likes and dislikes, pains and pleasures, successes and failures, to a sage of permanent peace, joy and selfless dedication to the entire creation" (Ponder \& Holladay, 2013).

'Four different types of yoga tourists are: yoga lite, yoga travelers, yoga practitioners and yoga professionals. The Major aim of yoga lite group is to learn simple yoga 'asanas' for pleasure and to live away from the rush; participate in a yoga workshop with a yoga teacher; insulate themselves from the material reality ... Yoga traveler: Yoga is not their sole reason to visit concerned places. They sometime try to learn postures but skip the class; they lack the search for authenticity. Some of them become yoga practitioner later. Major aim of Yoga practitioner is to learn yoga in greater depth; visit Yoga centers in search of inner quest and authenticity; keep regular practice in the ashram. Some of them become yoga professional later. Major aim of yoga professional is to receive the required authorization to teach yoga in their own country" (Ponder \& Holladay, 2013).

Butler et al. (2008) studied on 'Meditation with yoga, group therapy with hypnosis, and psychoeducation for long-term depression mood: a randomized pilot trail” in which they found these interventions show promise for treating low to moderate level of depression.

\section{Spiritual tourism}

Spiritual tourism is a new transformative approach of travelling with a core motive of experiencing peace of mind. "Spiritual tourism is defined as an act of travelling domestically or overseas to visit spiritual places such as mosques, churches and temples and natural environments such as forests, oceans, lake, spiritual gardens, wildlife parks for birds and animals, botanical gardens, caves, and rocks for spiritual reasons: to fulfill the need for being grateful to almighty, forgiveness and inner peace" (Haq \& Medhekar, 2019). Other scholars try to identify spiritual tourists differently: "spiritual tourists" are those who engage in religious practice or have spiritual experience in a religious context" (Norman, 2004).

Spiritual living is related to finding a meaning or purpose of life, peace of mind, unconditional love, a feeling of gratitude towards all and a sense of deep connection to the whole existence. Spiritual practice is living a purposeful life in a disciplined way for some higher goal. The ultimate aim of spiritual practices is to attain liberation, which is freedom from physical, emotional and karmic bondages. Living spiritual life requires following certain principles, ways and rules. According to Ramsukhadas (1993), "the journey towards liberation starts from worshiping the idols of Gods or Goddess, it deepens by visiting sacred places and practicing fasting and other rituals, then one attains wisdom by practicing meditation, and finally one attains a state of 
equanimity". Observations have shown that if the people who have materialistic goal in life pursue the path of spirituality, they grow prosperous in material prosperity and inner happiness as well. "Ananda or blissful state is the reason behind everything that exists" (Sarvananda, 1921, 6:1). Travelling is one of the aspect to experience this state of blissfulness.

Spiritual masters define this type of tourism as a journey apparently in the world but inherently a journey to the inner world. A spiritual tourist visits geographical places but deep down he is trying to know his inner self. Fear, insecurities, love, hate, pain, pleasure and so many thoughts and emotions stay in the mind. To know them as they are and to find the peace zone among them is the actual goal of a spiritual tourist. For spiritual tourist, the world is like a book, they read as many pages as they travel. Spiritual tourists are benefited mostly by being in the nature and meditation practices.

All above-mentioned tourism can be stated in a single phrase: wellness tourism. Wellness tourism is umbrella term under which all other tourism incorporate. Wellness tourism is defined by Smith and Puczko (2014; in Kunwar, 2019) as 'trips aiming at a state of health where the main domains of wellness (body, mind, spirit) are harmonized or balanced. There is emphasis on prevention rather than cure, but some medical treatment may be used to lifestyle based therapies.'

Mueller \& Kaufmann (2001) define Wellness as, "A special state of health comprising an overall sense of well-being which sees Man as consisting of body, spirit and mind and being dependent on his environment, this condition is called as great personal contentment, a high-level wellness."

Lengyel (2016) has observed tourists being open minded and receptive while travelling. Those very qualities are pre-conditions for learning meditation. 'A basic pre-condition for learning meditation techniques is to have an open, receptive, feminine attitude...Tourists poses a significantly elevated level of openness to new perspective. This increased openness together with an upward trend for spiritual experiences can create a synergy for certain destinations, accommodation types, tourism locations to expand their service portfolio with meditation based services" (Lengyel, 2016).

Meditation and tourism are perfect match for manifold reasons. "Meditation based tourism services are special products in the wellness sub segment of tourism." Meditation is a portable product which can be taken home and practiced totally cost free. There are clinically proven physical and psychological benefits of meditation. As people's interest in Complementary and Alternative medicine is growing, meditation has also been used as a therapy. Meditation is one of the technique that can be utilized in Complementary and Alternative therapy (Lengyel, 2016). A report revealed that 
mindfulness and mindful living as "Uber Trend" in wellness market (Lengyel, 2016).

Mindfulness seems to be able to contribute largely to becoming more sustainable mentally, psychologically, physically and economically as well. Mindfulness is linked with long-term sustainability. What actually unsustainable are a person's worldview, value system, concepts and way of thinking. Meditation is something that causes inner transformation concerning a person's worldview, value system and way of thinking. In meditation, a person is initiated to a systematic, regular and voluntary inner exploration and growth. The proven benefits of meditation can be the basis for a more sustainable world. It is needless to say, countless studies have explored farreaching benefits of meditation (Lengyel, 2016).

It is a welcome thing tourism is being associated with yoga or other spiritual aspects. This association has added many flavors in tourism sector. Some scholars believe that spiritual tourism is becoming a feather in hat for travelers. They are getting more healthy, harmonious and peaceful. They are developing wider perspective towards universal goodwill. Since the association of tourism with spiritual aspects is still in infantry, it has yet to incorporate some essential aspects of spiritual practices to have total benefits. In Buddhist philosophy, the important thing is to practice meditation and to involve in charity works. Meditation causes transformation in individuals and it is involving in charity works that helps developing compassion. In this article, an attempt has been made to explore these two aspects and how these can be incorporated in tourism activities. This research explores how spiritual tourism could help significantly in building world peace. Travelling can be a journey of meditation and dharma practices. It was the main purpose postulated by the ancient spiritual masters. However, this aspect has yet to be explored fully. This article attempts to fulfil this gap in contemporary research.

Norman, \& Pokorny (2017) has observed how meditation retreats are taking shape as spiritual tourism for well-being intervention. They have talked about subjective well-being extensively. They have scanned the mindful revolution and popularity of meditation. They have noted articles on the beneficial effects of meditation published in New York Times. Their observation is, since the 1970s, Buddhist meditation practices have seen increasing scholarly, scientific, and popular interest. Schedneck (2011; in Choe \& O'Regan, 2015) write, in recent time, Tourism Authority of Thailand is promoting 'meditation tourism." Brochures in English list meditation centers such as the Young Buddhist Association of Thailand, the Dhamma Kamala Meditation Centers, and International Buddhist Meditation Centers and so on. The above study shows the new genre "meditation tourism" has gradually entered and accepted in academia. 
Bhandari (2019) researched on "Tourism and the geopolitics of Buddhist heritage in Nepal" however; he has not explored the pilgrim's spiritual purpose in his article. Nyaupane (2009) explored 'Heritage complexities of tourism: A case of Lumbini, Nepal" in which he presents local non-Buddhist people's interest and government interest creating complexities in developing Lumbini as it should. A significant number of tourists visit Nepal seeking the improvement of health condition. Khanal \& Shimizu (2018) argue, 'Nepal has immense potentialities of health tourism.' Health is a wider concept these days incorporating physical, mental and spiritual health.

\section{Why meditation?}

The goal of Buddhist philosophy and practice is to attain Nirvana, the state of ultimate peace of mind. Meditation and wisdom both lead towards Nirvana. Buddha says, "There can be no meditation in one who lacks wisdom. There can be no wisdom in one who lacks meditation. He who has meditation as well as wisdom is, indeed,

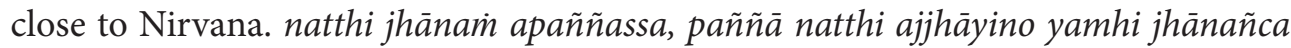
pañ̃̃ā ca, sa ve nibbānasantik (Buddharakshit, 1985, Dhammapada verse 273). This verse indicates the importance of meditation in Buddhism.

Defining meditation, Nyanatiloka (1970) says, in Buddhist terms, there is a special word Bhavana, which roughly translates in English as Meditation. Bhavana is 'mental development by developing tranquility, i.e. concentration and insight, i.e. wisdom. Meditation helps to see things as they are. As light destroys darkness, light of insight or knowledge destroys the darkness of ignorance (pp. 31-32).

According to Pali and Sanskrit texts, meditation rejuvenates one's energy level and zeal. It is proven by many scientific researches on meditation practitioners. That is why; its popularity is increasing in present days. It has gained huge following worldwide. Meditation is main part of Buddhist Dharma practitioners. When meditation is practiced in sacred places like Lumbini, its benefits are multiplied due to the positive energy field existing there. A mediation course helps every practitioner to relax and explore the spiritual aspects within.

Meditation has gained immense popularity in last decade. However, In Lumbini, there are still very few centers where people can practice meditation according to their conveniences. Since Lumbini is the most sacred place for Buddhist pilgrims, there should be enough meditation centers convenient for every type of tourists and pilgrims.

Vipassanā is Buddhist way of meditation. Buddha rediscovered this technique during his meditation practice under the Bodhi tree. In Buddhism, meditation is developed as a genre. Buddha has talked about meditation in countless teachings. There is a special sutta on meditation in Digha Nikaya 'Mahāsatipațthāna Sutta" (Digha Nikaya 22). Meditation is a process of self-purification by self-observation. The core 
practice starts by observing natural breathing as a means to develop concentration. During the whole course, the practitioner develops present moment awareness to a heightened level. With the sharpened awareness, one proceeds to observe the changing nature of the body sensations, the mental contents and experience the universal truth of impermanence, suffering and no self.

Vipassanā mediation or the Dharma practice is universal remedy for universal concerns and it has nothing to do with any organized religion or sectarianism. For this reason Vipassanā can be practiced by all people, without conflict of race, caste or religion and it will prove equally beneficial to all. SN Goenka (1995) has said, Vipassanā is an art of living and it frees every individual from all negativities of the mind such as craving, hatred and ignorance (pp. 98-99).

There are plethora of literature produced on wellness tourism; however, hardly any researcher has focused on meditation tourism in Lumbini and its significance. Every year, especially during the time of Buddha Purnima celebration, a huge number of Buddhist devotees and practitioners from hundreds of countries visit Lumbini to practice meditation. According to (Kunwar \& Ghimire, 2012), 99508 tourists visited Lumbini in 2010, this number increased to 128259 in 2011. This number is increasing every year. According to Lumbini Development Trust (LDT) (2018), the number of tourist who visit Lumbini in 2017 were 1552586. The same source recorded a total 1534110 tourists in 2018. Burmese, Thai, Sri Lankan, Chinese monks and devotees can be seen sitting in meditation under the trees in Mayadevi Temple premises. They either chant the Buddha's teachings or simply go into silent meditation.

Norman \& Pokorny (2017) have observed that, 'In many Buddhist community groups, meditation retreats are understood as opportunities for individuals to refine their meditation practice and therein develop habits to promote well-being. Meditation is taught variously as a technique of personal insight, emotional stability, and psychological ease" (Article in Press).

\section{Relation between meditation tourism and Buddhist philosophy}

Buddhism is the religion of travelers. From the very beginning, Buddha instructed his disciples to travel places, practice meditation and teach Dharma to help people get rid of suffering. Therefore, there is strong relation between meditation tourism and Buddhist philosophy. In Buddha's teachings, there are several statements to support this relation.

In Mahāvagga (I.II), Buddha asks his realized disciples to visit as many places as possible for helping people see the joy of practicing of Dharma. So, the purpose of tourism in Buddhist philosophy is dissipating the teachings of Buddha (Dharma) to as many people as possible. Buddha said to his disciples, "Go now and wander for the welfare and happiness of the many, out of compassion for the world, for the 
benefit, welfare and happiness of gods and men. Teach the Dhamma that is good in the beginning, good in the middle and good in the end, with the meaning and the letter. Explain a holy life that is utterly perfect and pure. There are beings with little dust on their eyes who will be lost through not hearing of the Dhamma. Some will understand the Dhamma" Mahāvagga (I.II).

Buddha instructed his disciples not to worship the statue of Buddha. He asked bhikkhus to get inspired to practice Dharma while visiting the pious environment of pilgrimage sites (Maha-parinibbana Sutta, 2019). Buddhist philosophy also suggests the same thing. Buddhist philosophy is not something for intellectual discussion. Rather, the whole Buddhism is based on practical aspects. Knowledge and conduct always go together. In Dhammapada, Buddha has said, "If you do not meditate, how will you gain insight? and if you have no insight, how will you concentrate? But if you concentrate with insight, you will come near Nirvana" (Buddharakshita, 1985, Dhammapada verse 372). caratha cārikām is the typical phrase Buddha used to inspire his disciple to visit places and practice meditation. camkramana refers to walking meditation. caratha cārikām appear in Mahavagga (I.II).

In Buddhism, Lumbini is revered as a sacred place to visit and practice meditation. In Mahaparinibbana sutta (2019), Buddha says, “These, Ananda, are the four places that a pious person should visit and look upon with feelings of reverence. And truly there will come to these places, Ananda, pious bhikkhus and bhikkhunis, laymen and laywomen, reflecting: 'Here the Tathagata was born! Here the Tathagata became fully enlightened in unsurpassed, supreme Enlightenment! Here the Tathagata set rolling the unexcelled wheel of the Dhamma! Here the Tathagata passed away into the state of Nibbana in which no element of clinging remains!"

Across Asia, several locations and spiritual sites associated with Buddhism or the historical Buddha are now part of tourism circuits. Latest developments in tourism have contributed to revitalize Buddhist sites. Research on the relation between meditation and Buddhist philosophy remains scant. It is quoted above that Buddha himself suggested his followers to visit sacred places related to the Enlightened One. Buddhist worldview plays significant role in shaping travelers' journey towards higher goal.

The Buddhist practitioners' visit is meaningful in many senses. Most of them are follower of Buddhist way of life. They are aware of meditation practices and sharing compassion to the needy ones. The more a tourist is aware of the Buddhist philosophy and practice, the more he or she reap the benefits.

A group of French tourists visited Lumbini on 17th, 18th and 19th May to practice meditation and to participate in Buddha Purnima Celebration. It was a meditation tour to Lumbini, which became the source of first-hand experience of the 
participants. This researcher, as spiritual teacher, led the group of 16 French tourists to guide them into meditation and Buddhist practices. They were happy to practice meditation and prayers in the morning and to see the Pooja, Light Ceremony in the evening of Buddha Purnima.

One of the tourists, Carol (pseudo name) shared her experiences with this researcher. She said, "Being inside the premises of Mayadevi Temple, where Lord Buddha was born, was an exhilarating experience. I could feel the Buddha energy in the milieu. Everything inside the premises was sacred and everyone delighted me to be there. I experienced as if Buddha is still there. The corporeal existence some 2500 years before is still leaving positive vibration around. I felt lucky to be there. Another tourist Katherine (pseudo name) said, "it was nice experience to visit Buddhist sites. The sacred environment was appealing to the heart and mind. I could see people gathered from all over the world to celebrate Buddha Purnima. They were happy and peaceful. It was good to be among happy people."

Similarly, Nanny (pseudo name) revealed, "I experienced good energy and serenity in the air inside the temple premises. I was connected with the trees, the pond, the greenery and everything." Herbert (pseudo name) told, "Buddha taught us to like ourselves, to find the peace in ourselves, to love ourselves. I practice what Buddha says, now I feel peaceful, I like everyone, I love everyone." Other participants expressed similar experiences. This tour was conducted during 11 May 2019 to 23 May 2019, which was managed by a tour operator in Kathmandu.

The participants' versions including their experiences reveal the importance of meditation tourism in Lumbini. The analysis of their experiences can be categorized in three ways. First, every participant who visited the holy place Lumbini was inspired deeply to find peace of mind. They were very much aware of Buddha's enlightenment and his boundless compassion towards all suffering people. The participants were motivated to attain enlightenment like Buddha. The second aspect is, the participants practiced meditation under a tree inside the Mayadevi Temple. During this meditation, they experienced abundant positive energy in the milieu. The participants were so much happy. Everyone was feeling good to be there. It was quite a different experience to them.

The third aspect is they were moved deeply by observing the Buddha Purnima celebration. They could see people gathered in Lumbini from all over the world. Almost everyone was inspired, every pilgrim could be seen full of happiness and devotion. Meditation tour in Lumbini was one of the enriching experience of their life. The participants were cheerful and peaceful due to the spiritual vibration available in Lumbini. This inner enrichment helped them realize the importance of attaining Nirvana, the peace of mind and being compassionate towards all living beings. 
The core aspect of Buddha's suggestion to visit Lumnini was to inspire people to practice meditation to attain Nirvana, the state of peace and to fill their heart with loving-kindness. The participant's experience is similar as Buddha suggested. Their experience reveals the true significance of visiting Lumbini. A conclusion can be drawn that meditation tourism to Lumbini is putting Buddhist philosophy into practice, which benefits the tourist and the holy destination as well. Meditation tourism in Lumbini can be prosperous for the development of Lumbini as a fountain of world peace.

\section{The authenticity of Lumbini for meditation tourism}

The authenticity of Lumbini as birth place of Buddha is declared by evidences such as scriptures, historical/archeological evidences and academic research. However, the spiritual growth of a pilgrimage requires to follow the teachings and dharma practices as instructed by Buddha.

Lalitvistara, a Mahayana Buddhist Sutra has revealed the ritual and its spiritual significances. The text says, "As soon as he was born, the Bodhisattva stepped onto the ground. Wherever his feet touched the ground, a large lotus immediately sprung from the earth" (Lalitvistara, 2013, p. 64). At the same time, he announced 'this is the last birth; there is no more coming to be.' It indicates that Buddha was enlightened since the very birth. Buddha was born in Lumbini. Buddhism also began from Lumbini. The whole Lumbini region is spiritually saturated since the time of Buddha. It is recommended by Lord Buddha himself that visiting "Lumbini will empower every pilgrimage spiritually" (Mahāparinibbāna Sutta, 2019).

In Lumbini, a tree is not only a tree. A pond is not only a pond. They have deep spiritual meaning. Buddha's birth, youth, his renunciation and awakening to Buddhahood all these have close connection with the greenery, environment and the whole nature of Lumbini. Lord Buddha was born under a tree, realized Nirvana under a tree and finally, he entered into to Mahäparinibbāna while resting under trees. There is deep connection between awakening and nature. According to Lalitvistara Sutra, Buddha chose Lumbini due to its purity. The text says, "Buddha contemplated on the purity of the particular time, the particular location in the earth planet and the family and he made the choice" (Bajracharya, 1999). It reveals that the soil, the air and the whole environment of Lumbini is sacred since the time of Gautama the Buddha.

In Lumbini, even inanimate things are regarded or respected as living entity. It is widely believed that existence is a living organism, a person is part of it. He or she is supposed to take care, love and respect the whole creation as he does to himself or herself or to near and dear ones. Doing so, one receives a lot cosmic energy for happiness and peace. Nepalese people seem to be spiritually motivated since time 
immemorial. Apparently, the Hindu temples and Buddhist monasteries follow different rituals, worshiping ways and beliefs, however, deep down, they have spiritual significance. The underlying meaning behind each and every ritual is to liberate the practitioners from the bondage of life.

Kunwar \& Ghimire (2012) have presented the authenticity and significance of Lumbini well established as international destination for tourism. Kunwar (2006, p. $250 ; 2017$, p. 333) has suggested the concerned authority to build a maternal hospital in Lumbini so that pregnant women and their family would visit Lumbini for the delivery. He argues, both guest and host would benefit from this. The parents could link their babies to Buddha who were born in sacred groves.

The significance of visiting the birth place of Buddha: In the birth place of Buddha (Lumbini), there is a wide milieu of tremendous amount of positive energy. Thousands of enlightened disciples of Buddha are still visiting that place and sitting in meditation. A pious energy field is always intact around Mayadevi Temple and whole Lumbini area. Science says, energy can neither be created nor destroyed. Energy can only be transferred from one form to another. The pilgrims visit Lumbini to resonate with that energy field. How much one resonates the vibration of enlightenment depends on the capacity of every receptor.

Buddha once said, I am not the first Buddha to come upon the earth, nor shall I be the last. Previously there were many Buddha who appeared in this earth planet. Historical evidences are also available of these Buddhas in Lumbini. Krakuchhanda and Kanakamuni Buddha were born in Lumbini before Gautama the Buddha. According to Ashoka Pillars, Krakuchhanda Buddha was born in Gotihawa and Kanakamuni Buddha was born in Niglihawa.

\section{Overview of meditation centers and practices in Lumbini}

In Lumbini there are two main meditation centers. One is Dhamma Janani in which vipassanā is practiced as taught by Satyanarayan Goenka. This center runs meditation retreats twice a month. In Dhamma Janani, 200 hundred participants can practice meditation in the hall but the accommodation is limited to 48 male and 48 female. The payment is donation based. In tourist season 90 percent participants are foreigners. In other months, the foreign and national participants are almost equal in number. Meditation instructors are appointed by Dharma Shringa named as Nepal vipassanā meditation center in Kathmandu. The meditation instructors are called Assistant teachers. They have to complete several long courses on meditation to be qualified as assistant teacher.

There is another meditation spot named Panditarama Lumbini vipassanā meditation center. In this center, same meditation is practiced but according to another Burmese tradition. In Panditaram a little less number of accommodation is available. 
The payment is donation based. In this center, one male and one female meditation instructors are available as residential teacher. Both instructors are foreigners. The teachers are expected to be highly qualified in knowledge and practice of meditation. International Bauddha Bhavana Kendra, Myanmar appoints the teachers. The willing participant has to communicate with the authority via their website.

There are dozens of monasteries inside monastic zone in Lumbini. Monasteries are built for serious meditation practice. However, these monasteries are not running regular meditation courses. They organize such courses only once in a year at the time of Buddha's birthday celebration.

Lumbini Buddhist Univeristy's central campus in Lumbini has built a meditation hall. However, there is no regular meditation. Untill now, this is the actual state of the availability of meditation centers in Lumbini. Even if the tourists find some time to sit in meditation, they do not find a place for it. Some individuals are practicing meditation in monasteries and residence as well, however, for mass meditation, the infrastructures are really lacking. The stakeholders should be concerned about this situation.

\section{Putting philosophy into practice}

Buddhist philosophy is based on three pillars - Following the five precepts, Practicing Meditation and attaining Wisdom (śila, samādhi, prajñā). Buddha's Noble Eight-fold Path reveals the ways of Dharma practice and the ultimate goal of Enlightenment or Nirvana. Nirvana is peace and happiness (Buddharakshita, 1985, Dhammapada verse 203). Buddhism consists doctrines such as the law of dependent origination, the five aspects of knowledge, the doctrine of Emptiness, the concept of Buddha Nature, the mind-only philosophy and so on.

Buddhism is practice based spiritual tradition. The insight is philosophical aspect but meditation is something to be practiced. It is stated above that these two should always go together. In this path, knowing is not enough. One has to analyze the nature of things from every aspect and experience the knowledge by the practice of meditation. The knowledge that is practiced becomes liberating. Some of the practices are: Reading or listening - analyzing - experiencing (śrutamay $\bar{\imath}$ prajū $\bar{a}$, cintanamay $\bar{\imath}$ prajūā, bhāvanāmaȳ prajñā), (Goenka, 1993) the ways of the Bodhisattvas, The six excellence (șațāramitā), Samatha and Vipassanā Meditation.

Spiritual philosophy expects to understand life and the world as it is. Right understanding leads to wisdom and wisdom leads to final liberation. Consequently, all sorts of suffering could be overcome; one realizes the inner peace and serenity. $\mathrm{He}$ or she attains peace of mind. Once a person realizes his true nature, he develops a sense of gratitude towards every person, event or things. It breeds happiness and joy. Consequently, he or she develops compassion towards all who are still suffering, 
who are still not being able to see life and the world as it is, who are not being able to overcome their suffering.

Visiting temples, monasteries, stupas and other pilgrimage sites is introducing the visitor about several spiritual aspects. In every idol, Buddha is depicted in certain meditation pose performing certain mudra. These practices have deep spiritual connotations. Attaining final liberation requires to apply the understanding into practice. Visiting sacred sites like Lumbini inspires the devotees and lay men towards Meditation practices which is deeper understanding of the mind and matter. It is coming closer to the core of everything that exists and seeing things clearly, as they are. Mahāsatipațthāna Sutta (1996) says, "Having experienced things as they really are, the arising of sensations, their passing away, the relishing of them, the danger in them and the release from them, the Enlightened One, monks, is fully liberated being free from all attachments."

When a person visits a temple or a monastery, he or she offers several things to the statues established there. Lighting an oil lamp, offering a beautiful flower or some good food or money, chanting some mantra or dancing are different kinds of offerings. Among all offerings, the offering of one's best possessions, one's positive state of mind is significant. These offerings helps to purify ourselves and regain the ultimate understanding of Advaya (non-duality). Buddha says, "Practicing vipassanā, one will achieve Nibbana" (Goenka, 1993).

Buddhist pilgrims are interested in practicing meditation, which is a key practice of Dharma. There are many types of meditation such as Mindfulness meditation, Metta meditation, insight meditation and so on. Vipassana mediation is the root of all. It is expected to learn these practices with an authorized teacher and practice diligently. The basic Vipassanā course completes in ten days. "To learn Vipassanā it is necessary to take a ten-day residential course under the guidance of a qualified teacher" (Khin, 2000). For the duration of the retreat, the meditation practitioners stay in meditation center. They cannot have any contact with the outside world. They are not allowed to read or write and they have to suspend any religious practices of similar activities under other tradition. "They (the practitioners) follow a daily schedule, which includes about ten hours of sitting in meditation. They also observe silence, not communicating with fellow students" (Khin, 2000). However, the practitioners are allowed to ask their queries about the practice with the assistant teachers.

Vipassanā is a technique of training the mind. The actual practice has three steps. "First, students practice abstinence from actions, which cause harm. They undertake to observe the five moral precepts, practicing abstention from killing, stealing, lying, sexual misconduct and the use of intoxicants" (Khin, 2000). The observation of these 
precepts let the mind stand still and prepare to go ahead with other steps. "Second, for the first three and half days, students practice Anapana meditation, focusing alteration on the breath. This practice helps to develop control over the unruly mind" (Khin, 2000).

The above mentioned two steps (living in a wholesome way and developing control of mind) are essential and in many ways beneficial. However, one cannot progress in meditation if third step is not taken. The third step is focused on purifying the mind of underlying negativities. "The third step, undertaken for the last six and a half-days, one penetrates one's entire physical and mental structures with the clarity of insight" (Khin, 2000).

In the introduction, it is stated how instructions are given to the practitioners. Students receive systematic meditation instructions several times a day, and each day's progress is explained during evening discourses by Goenka. Complete silence is observed for the first nine days. In the tenth day, students resume speaking, making the transition back to a more extroverted way of life. The course concludes on the morning of the eleventh day. The retreat closes with the practice of maitri bhavana (loving kindness or good will towards all) in which the purity developed during the courses is shared with all beings.

\section{Putting compassion into practice}

Buddhism inspires to practice meditation to attain peace of mind. As the mind becomes peaceful, the wisdom arises in the practitioner. Wisdom is to see things as they are. This liberates the practitioner from suffering. Once the suffering comes to an end, the enlightened person is filled with boundless compassion towards all living beings. Prajñayā na bhavē sthānaì krpayā na śamē sthitị̆ (Maitreyanath, 1999). According to Buddhist philosophy, the enlightened beings are gone beyond the world of suffering but they are still around because of the compassion towards those who are suffering.

Dharma practitioners in Buddhism has to excel in charity. Shantideva (2001) says that perfection in charity is achieved when a practitioner gives everything to every sentient beings and gives up the fruit of charity as well (p. 21). While involving in charity, the practitioner should be careful to the right places. One should either give or help to parents or elders who were helpful for the practitioner (punya Chhetra), the actual people who are suffering (Dukkha Chhetra) and the Buddhas, Pratyekbuddhas, Arhantas, Bodhisattvas, Shravakas, Shramanas and Brahmanas, Teachers and Kalyanmitras (Guna Chhetra).

Rijal (1999) says, there are three types of charity - The first is Amish Dana, it is giving goods, jewels, money, food or medicine. The second is Abhaya Dana, it is helping the fearful or restless people to come out of fear or restlessness. The third is 
Maitri Dana, it is imparting loving kindness during meditation practice to people so that they could live happily. The fourth is Dharma Dana, it is guiding or inspiring people to follow the path of Dharma (p. 99).

If charity is not practiced with compassion in heart, it may not be pure charity. So, while practicing charity, one's heart should always be full of compassion. To attain the perfection of charity, one has to be aware of the emptiness of all phenomena. With this awareness, one should learn to see emptiness in all three aspects involving in charity works such as the giver, the receiver and the gift (Rijal, 1999, p. 99). Charity practiced in such way is perfection in charity and it becomes helpful in purifying the mind and attaining the Nibbana. Every pilgrim is expected to practice charity while visiting Buddha Chhetra such as Lumbini. The aim of meditation tour to Lumbini is purifying the mind, practicing generosity and getting inspired for attaining Nibbana.

\section{Discussion}

Meditation tourism may contribute to whole tourism industry in several ways. Meditation tourism may breed peaceful individuals who will inspire many people to visit places for meditation purpose. This can begin with meditation tourism to Lumbini. Therefore, this study suggests the stakeholders to build meditation centers where accommodation, teachers, facilities and required interpretations are available. This tourism helps to establish some ethical values such as non-violence. Buddha suggested non-violence as first precept but in Lumbini, there are many slaughterhouses. This is not ethical according to Buddhism. Meditation practitioners will avoid nonvegetarian food; killing animals in Lumbini will slowly come to end. As people find peace of mind during meditation, they will be ready to pay the meditation centers. They will spread the good aspects of meditation tourism all over the world, which will ensure more tourists in Lumbini than ever before. Everyone who visits Lumbini will pay for the cultivation of mind, for gaining peace of mind. Visitor should be aware of the authentication of mediation tour in Lumbini and its benefits. This tourism will help the locals, the particular place Lumbini and the country as a whole in being benefited financially and spiritually. Lumbini will be renowned internationally as the fountain of peace.

\section{Conclusion}

The above study reveals that meditation tourism is an emerging aspect of wellness tourism. Meditation tourism to Lumbini is a new area of study, which is full of potentials for individual, local and national development. The tourists who visit Lumbini for meditation purpose can be benefited immensely if they understand the core values of Buddhism, practice meditation accordingly and involve in some charity works. The Buddha's teachings reveal that meditation helps to attain Nirvana, which is finding peace of mind and developing compassion. Meditation tour to 
Lumbini can be helpful to attain Nirvana more easily than elsewhere. Lumbini is the best destination for meditation tour and the practice of compassion. The pilgrims are highly recommended to understand these core aspects of Buddhism and practice the same for the good. Meditation tourism is getting popular. However, in Lumbini, there are still very few centers where people can practice meditation according to their conveniences. Since Lumbini is the most sacred place for Buddhist pilgrims, the stakeholders are expected to build meditation centers convenient for every type and categories of pilgrims. Building convenient meditation centers or offering financial and other services will be a best charity work for the practice of true Dharma. As Frost (1984) famously said, the roads diverge at some point in everyone's life. If one happens to choose less travelled road, it will make the difference in life. The inner journey with the practice of meditation is something less travelled.

\section{References}

Bajracharya, D.V. (1999). Nava Sutra Sangraha, Taiwan: The Corporate Body of Buddha Education Foundation.

Bhandari, K. (2019). Tourism and the geopolitics of Buddhist heritage in Nepal. Annals of Tourism Research, 75, 58-69. https://doi.org/10.1016/j.annals.2018.12.006

Berg, B.L. \& Lawrence, L.H. (2012). Qualitative Research Methods for the Social Sciences (8th Ed.), Boston: California State University.

Bowers, H. \& Cheer, J. M. (2017). Yoga tourism: Commodification and western embracement of eastern spiritual practice. Tourism Management Perspective, 24, 208-216.

Buddharakshita, (1985). Dhammapada. Sri Lanka: Buddhist Publication Society.

Butler, L. D. et al. (2008). Meditation with yoga, group therapy with hypnosis, and psycho-education for long-term depressed mood: A randomized pilot trail. Journal of Clinical Psychology, 64 (7, 806-820).

Choe, J. \& O’Regan, M. (2015). Case Study 2 : Religious tourism experiences in South East Asia, in Raj. R. \& Griffin, K. (Eds.) Religious tourism and pilgrimage management: An international perspective, 2nd Edition(pp. 191-204), Vallingford: CABI.

Digha Nikaya (2013) : Maha-satipatthana sutta: The Great frames of Reference (Digha Nikaya 22), Thanissaro Bhikkhu, (Trans.) Access to Insight, (BCBS Edition, Date accessed 21 June, 2019, https://www.accesstoinsight.org/tipitaka/dn/dn.22.0.than. html

Maha-satipatthana sutta (1996). "Brahma-Jala Sutta" (Digha Nikaya 1.16) USA, Vipassana Research Institute. 
Dillettee, A. K. (2019). Yoga tourism - a catalyst for transformation. Annals for Leisure Search, 22, 1, 22-41.

Frost, R. (1984). Complete poems of Robert Frost. United States of America: Holt, Rinehart and Winston.

Ganguli, K.M. (2003). Mahabharata (Ashwamegha Parva, 14). Culcatta: Bharata Press.

Goenka, S.N. (1993). Mahāsatipațthāna Sutta The Great Discourse on the Establishing of Awareness, USA: Vipassanā Research Institute.

Goenka, S.N. (1995). Pravachan Saramsa. Igatpuri: Vipasana Vishodhan Vinyas.

Haq, F. \& Medhekar, A. (2019) Spiritual tourism: A peace vehicle for social transformation and economic prosperity in India and Pakistan? in Nedelea, A.M. \& Nedelea, M.O. (Eds.) Marketing Peace for social transformation and Global prosperity, USA: IGI Global, (189-211).

Heidari, A. Yazdani, H.R, Saghafi, F. \& Jalilvand, M.R. (2018). The perspective of religious and spiritual tourism research: A systematic mapping study. Journal of Islamic Marketing, 9, 4, 747-798.

Khanal, B. \& Shimizu, T. (2018). Factors affecting the development of health tourism in Nepal: Regarding the views of health tourists. Journal of Tourism Research and Hospitality, 7, 3.

Lengyel, A. (2016). Tourism, Meditation, Sustainability. College of Szolnok, Applied studies in Agribusiness and commerce. APSTRACT: Applies studies in Agribusiness and Commerce, 10, 1, 81-92.

Kunwar, R. R. (2017). Tourists and Tourism: Revised and Enlarged Edition. Kathmandu: Ganga Sen (Kunwar).

Kunwar, R.R. (2006). Tourists \& Tourism: Science \& Industry interface. Kathmandu: International School of Tourism \& Hotel Management.

Kunwar, R.R \& Ghimire, H.L. (2012). Lumbini as international pilgrimage destination: Authenticity and significance. The Gaze, Journal of Tourism and Hospitality, 4, 1, $1-33$.

Kunwar, R.R. (2019). Medical tourism and hospitality in hospital. The Gaze, Journal of Tourism and Hospitality, 10, 67-123.

Khin, S.U.B. (2000). Vipassanā Meditatioin Introduction, Dharmashringa: Nepal Vipassanā Center, Kathmandu.

Karki, N. (2018). Book review. International handbook on tourism and peace. Journal of Tourism and Hospitality Education, 8, 97-106. 
Lumbini Development Trust (LDT) (2018), Date accessed 06-09-2019. https:// lumbinidevtrust.gov.np/en/home/news/details/89

Maitreyanath, (1999). Abhisamayalankar, quoted in Bauddhadarsha, Kathmandu: Vyoma Kusuma Anuvada Samiti.

Mahāsatipațthāna Sutta: The Great Frames of Reference (DN 22) Burma Pitaka Association (Trns.). Access to Insight (BCBS Edition), Date accessed, 01-062019. https://www.accesstoinsight.org/tipitaka/dn/dn.22.0.bpit.html

Medhakar, A. \& Haq. F. (2019). Promoting Kashmir as an abode of peace tourism destination by India and Pakistan, in Nedelea, A.M. \& Nedelea, M.O. (Eds.) Marketing Peace for social transformation and Global prosperity, USA: IGI Global.

Moufakkir, O \& Kelly, I. (Eds.) (2010). Tourism, Progress and Peace. United Kingdom: CABI.

Nyaupane, G.P. (2009). Heritage complexity and tourism: The case of Lumbini, Nepal. Journal of Heritage Tourism 4(2): 157-172.

Norman, A. (2004). Spiritual Tourism: Religion and Spirituality in Contemporary Travel. An unpublished Bachelor Degree Thesis: University of Sydney.

Mueller, H. \& Kaufmann, E.L. (2001). Wellness tourism: Market analysis of a special health tourism segment and implications for the hotel industry. Journal of Vacation Marketing. 7 (1, 5-17).

Norman, A. \& Pokorny, J.J (2017). Meditation retreats: Spiritual tourism well-being interventions. Tourism Management Perspectives. Retrived from http://dx.doi. org/10.1016/j.tmp.2017.07.012

Patanjali (1998). The Yoga Sutra of Patanjali, Varanasi: Motilal Banarasidas.

Nyanatiloka (1970). Buddhist Dictionary. Singapur: Singapur Buddhist Meditation Center.

Ponder, L. M. \& Holladay, P. (2013). The transformative power of yoga tourism. South Carolina National Heritage Corridor, University of Saint Francis, Joliet, Illinois, USA, Date accessed, 29 May, 2019. https://www.researchgate.net/ publication/286501602

Pratt, S. \& Liu, A. (2015). Does tourism really leads to peace: A global view. International Journal of Tourism Research, 18 (1), 82-90.

Rijal, N.P. (1999). Bauddhadarsha. Kathmandu: Vyoma Kusuma Anuvad Samiti.

Ramsukhadas (1993). Srimad Bhagavad Geeta. Gorakhpur: Geeta Press.

Sarvananda, S. (1921). Taiteriya Upanishad, Madras: The Ramakrishna Math. 
Shantideva (2001). Bodhicharyavatara, Varanasi: Bauddha Bharati.

Satyananda, S. (2002). Asana, Pranayama, Mudra, Bandha. Bihar: Yoga Publication Trust.

Sarvananda, S. (1921). Taiteriya Upanishad, 6:1. ānandādēva khalvimāni bhütāni jāyantē. Madras: Ramkrishna Math.

The Play in Full (Lalitvistara) (Trns.) (2013). published by 84000, Dharma Chakra Translation Committee.

Vajira, S. \& Story, F. (Trns.) (2019). Maha-Parinibbana Sutta: Last Days of the Buddha (DN 16) Access to insight (BCBS Edition). https:/www.accesstoinsight.org/ tipitaka/dn/dn.16.1-6.vaji.html 